\title{
ANIMAL REPRODUCTION SCIENCE
}

\section{Review article}

\section{QTL and candidate genes for fecundity in sows}

\author{
Bernd Buske*, Ina Sternstein, Gudrun Brockmann \\ Humboldt-University of Berlin, Agricultural and Horticultural Faculty, Institute of Animal Sciences, \\ Department of Breeding Biology and Molecular Genetics, 10115 Berlin, Invalidenstr. 42, Germany
}

Received 30 May 2005; received in revised form 12 December 2005; accepted 28 December 2005

Available online 7 February 2006

\begin{abstract}
Fecundity in pigs is a trait of major economic interest but low heritability. For the improvement of fecundity, genetic markers for selection are desirable and therefore, several searches for genetic variation influencing fecundity have been performed. The aim of this review is to compare and to evaluate all published QTL analyses and candidate gene approaches concerning reproductive traits in sows. For this purpose, we present a comprehensive cytogenetic map comprising 54 QTL and 11 candidate genes with influence on reproductive traits. The evaluation and comparison of the results showed similarities, but also marked differences among studies. Reasons for different results are multicausal and are due to differences between resource populations, number of evaluated animals, mating systems, measured phenotypical traits and environmental influences. We could show that chromosome 8 and to a lower extend chromosome 7 are the most important chromosomes with regard to reproductive traits in pigs. For further research, fine mapping of the identified QTL regions is necessary in order to confirm and to narrow the most likely chromosomal intervals. Although difficult to perform, an advance would be a standardization of the experimental setup in particular, in respect to the collection of phenotypic data. Furthermore, we suggest to publish the information on further identified QTL and candidate genes as comprehensive and accurate as possible in order to allow a more transparent comparison and collation of the results.
\end{abstract}

(C) 2006 Elsevier B.V. All rights reserved.

Keywords: Candidate gene approach; Cytogenetic map; Fecundity; Pigs; QTL analysis; Reproductive traits

\section{Introduction}

The improvement of reproductive traits in livestock species has become of expanding interest especially in pigs, where moderate increases in litter size can equal large gain in profit (Short et al.,

\footnotetext{
* Corresponding author. Tel.: +49 302093 6449; fax: +49 3030936397.

E-mail address: bernd.buske@staff.hu-berlin.de (B. Buske).
} 
1997; Vincent et al., 1998). However, until now, selection programs are almost only based on phenotypical traits which are laborious, expensive and especially in pig production time consuming. Marker assisted selection (MAS), employed in conjunction with traditional selection methods, could accelerate the rate of change in economically important traits. However, so far only little is known about genetic variability that can be used to improve fecundity by selection of favorite alleles. Two approaches have been pursued to identify genetic markers for reproductive traits: first, genome scans employing anonymous DNA markers like microsatellites have been used to identify quantitative trait loci (QTL) for reproductive traits (Rathje et al., 1997; Rohrer et al., 1999; Wilkie et al., 1999). Second, candidate gene approaches as a direct gene assay have been employed in order to find associations between the gene itself and a phenotypical trait (Rothschild et al., 1996; Drogemuller et al., 2001; Jiang et al., 2001; Lineville et al., 2001; Isler et al., 2002; Muñoz et al., 2004). Since 1996 when the estrogen receptor gene has been investigated with regard to influence litter size, several candidate gene and QTL analyses have been performed in order to find genes or regions with an impact on fecundity. However, until now, no gene itself with a causative mutation for such a trait has been detected through linkage analyses. Reasons for this failure are multicausal, e.g. low heritability and the fact that many genes contribute only for a small amount for fecundity parameters. There are two possible ways in which a gene can influence the productive performance: first, mutations in the coding regions of a gene may change the quality of the encoded protein, which is the case if mutations cause amino acid exchange, premature stop of translation or alternative splicing. Second, mutations in regulatory regions of the gene that affect the amount of transcripts of the gene in the cell and thus the amount of produced functional protein with unchanged quality. Concerning linkage and association studies, it cannot be distinguished between these two effects because both may cause measurable changes of the phenotype. However, major effects are often caused by severe changes of the primary protein structure causing a failure of the functional protein with dramatic consequences for the phenotype. Neutral amino acid substitutions as well as mutations in the regulatory regions are expected to cause small effect phenotypical changes. Our review bases only on association studies concerning candidate gene approaches and linkage studies concerning QTL analyses. Therefore, with linkage or association studies including candidate gene analyses we cannot distinguish between the two different types of effects. Finally, the aim is to find genes or at least closely linked markers to genes with an impact on fecundity in order to (pre-) select animals with the desirable genotype.

The aim of this article is to review the results of QTL analyses and candidate gene approaches with regard to fecundity in pigs. For this purpose, we present a comprehensive cytogenetic map comprising all published genes and QTL regions with an impact on fecundity. We compared the results, evaluated the reasons for the different findings and finally, give advice and strategies for further investigations.

\section{General aspects of QTL studies and candidate gene approaches for reproductive traits in pigs}

In order to detect loci for a special trait, there are in principle two strategies possible: QTL analysis and the candidate gene approach (Rothschild et al., 2000; Omelka et al., 2001). There is a general debate about which of these two strategies is more powerful in order to detect genes for reproductive traits in pigs. 


\subsection{QTL analyses}

For QTL analyses as an "indirect gene approach" so far, microsatellites have been used because of their high polymorphic structure. Rathje et al. (1997) stated that it is important to select markers that are informative within a specific resource population for a genomic scan. Because at least three generations are required, QTL analyses are time consuming and costly. Another aspect is, that is generally accepted that the distance between the genotyped markers should be $20 \mathrm{cM}$ or less, thus, a large number of informative markers is required. The resource populations consisted in crosses between animals of the breeds Large White, Landrace, Yorkshire, White composite and Chinese Meishan pigs. In general, animal numbers varied between 114 and 600 genotyped $\mathrm{F}_{2}$-sows and are rather low in comparison to QTL analyses performed with mice or to some candidate gene approaches performed with pigs. This is due to the fact that QTL analyses are more time consuming because of the long generation interval in pigs and because animals must be genotyped for many markers contrary to candidate gene approaches, where only one or a few genes are investigated. However, when only teat numbers were investigated, also males were genotyped and their breeding values for teat number were investigated, and hence animal numbers increased (Rohrer, 2000; Hirooka et al., 2001). The aim of a QTL analysis is the identification of genomic regions, which are responsible for a desirable trait. So far, no gene with a causative mutation has been identified, which underlies a detected QTL effect concerning reproductive traits in pigs. The reasons for this failure are multicausal, but in general, identified QTL regions are usually wide, which makes it difficult to define a candidate gene or genes underlying an observed QTL effect. Therefore, QTL fine mapping is necessary to narrow the chromosomal region harboring the QTL and thus the number of potential candidate genes. According to Khatkar et al. (2004), fine mapping of QTL for economic traits is at an early stage in livestock and should be extended in the future. Furthermore, it is generally accepted that in polygenic traits with low heritability such as fecundity in pigs, many genes account only for a small amount of the phenotypic variance. Heritabilities for litter size for example were estimated between 0.06 and 0.15 by Roehe and Kennedy (1995) and between 0.00 and 0.16 by Holl and Robison (2003). Moreover, it is difficult to standardize all environmental influences for a longer period, especially when working with pigs. However, this is strongly required when analyzing genes which contribute only for a small amount to the trait in order to separate genetical from environmental influences. Some further aspects, concerning limitations and methods for QTL analyses and candidate gene approaches with regard to reproductive traits in pigs are presented in Table 1.

\subsection{Candidate gene approaches}

The proportion of pig genes that have been mapped is still small and consequently, the number of positional candidate genes is limited (King et al., 2003). It is often mentioned that in principle every animal from any population can be investigated. Basically, this is feasible, and many research groups genotyped a candidate gene for a chosen trait at a given standardized $F_{1}$ - or $F_{2}$-population, depending on the breeding system. According to Rothschild et al. (2000) one requirement of the candidate gene approach is to test the gene variants in several populations to detect general effects. In general, the resource populations and the number of tested pigs in different experiments varied to a considerable amount. Some research groups used reference families, some used commercial pig populations, but only a few of them let the animals house in a commercial farm. Because of differences concerning housing, feeding and other environmental influences, results of these studies are difficult to compare. Rothschild et al. (1996) investigated 161 sows of a synthetic 
Table 1

QTL analysis in comparison to candidate gene approaches concerning reproductive traits in pigs

\begin{tabular}{|c|c|c|}
\hline Parameter & QTL analysis & Candidate gene approach \\
\hline Principle & Indirect gene assay & Direct gene assay ${ }^{\mathrm{a}}$ \\
\hline Costs & High & Moderate \\
\hline Number of genotyped animals & Middle (approx. 100-600) & Extremely different \\
\hline Accuracy & $\begin{array}{l}\text { Moderate because of the } \\
\text { recombination frequencies }\end{array}$ & $\begin{array}{l}\text { High, when the causative mutation is } \\
\text { detected }\end{array}$ \\
\hline Limitations & $\begin{array}{l}\text { At least three generations are } \\
\text { required }\end{array}$ & $\begin{array}{l}\text { In principle not any, each animal of a } \\
\text { population can be investigated }\end{array}$ \\
\hline Expressiveness & $\begin{array}{l}\text { No information concerning: how } \\
\text { many genes underlay the QTL; the } \\
\text { causative gene; the favorable allele }\end{array}$ & High, because of a direct gene assay \\
\hline Number of identified QTL/genes & Many (54) & Several (11) \\
\hline Probability to find further loci & Moderate & Moderate \\
\hline Suitability for use & $\begin{array}{l}\text { Indifferent, QTL dissipate with } \\
\text { further generations }\end{array}$ & $\begin{array}{l}\text { High, when the causative mutation is } \\
\text { known }\end{array}$ \\
\hline Difficulties & $\begin{array}{l}\text { Decision, which QTL should be } \\
\text { considered for further selection, } \\
\text { pleiotropic effects }\end{array}$ & $\begin{array}{l}\text { Genotype frequencies are often } \\
\text { unbalanced, pleiotropic effects }\end{array}$ \\
\hline
\end{tabular}

a Strictly speaking only, when a causative mutation is investigated with regard to expected influences on phenotypes.

Meishan line and 1079 sows of a Large White synthetic line for variants of the estrogen receptor gene (ESR). Short et al. (1997) extended the number of animals by the use of 4262 sows of Large White based commercial pig lines. An association study for the ESR gene with regard to litter size was also performed by Depuydt et al. (1999) using only 144 sows housed in 3 commercial pig farms. Van Rens et al. (2000) genotyped 79 Meishan $\times$ Landrace gilts for the ESR gene and evaluated the sows for luteinizing hormone, estrogen and progesterone. Matoušek et al. (2003) used two elite herds consisting of 178 and 144 Large White sows, respectively, in order to investigate litter size effects for the genes ESR and ryanodine receptor gene 1 (RYR1). For the prolactin receptor gene (PRLR), Vincent et al. (1998) used five populations consisting of Large White, Landrace, Duroc and Large White $\times$ Meishan pigs. Animal numbers varied between 261 and 416 sows. Li et al. (1998) investigated the follicle stimulating hormone beta gene (FSHb) with regard to litter size. All pigs in this study descended from nucleus herds in China and consisted of Landrace, Duroc and of a Yorkshire $\times$ Erhualian synthetic line. They investigated litter size parameters, and for the first parity, 289 sows could be evaluated, whereas for the fourth parity, only 52 sows were available. This led to only two different genotypes in sows with four litters, compared to sows with only one litter, where all the three genotypes were found. A total of 2545 litter records of 1300 sows from commercial lines consisting of Large White, Landrace and Duroc housed in a genetic nucleus farm, were evaluated for the retinol binding protein 4 gene (RBP4) by Rothschild et al. (2000). The authors concluded that a very large data set is needed to show significant differences for allelic effects in a range of $0.2-0.25$ piglets/litter observed in their study. Similar conclusions were drawn by Muñoz et al. (2004). They investigated the ESR2 gene with regard to the total number of born pigs in 2 Iberian pig lines with 46 and 150 sows, respectively. They were not able to find significant differences between genotypes and proposed a further investigation with more animals. The problem is, especially when animal numbers are low, that it is rather unlikely to obtain balanced genotype frequencies. Often, phenotypic selection over many years leads to loss of rare alleles if they are not strongly linked to the selection aim. Hence, rare genotypes cannot be evaluated with sufficient statistical 
power. In order to obtain more balanced genotype frequencies, a special mating test is required. This could be achieved by crossing phenotypically extreme different breeds or by crossing animals which are opposed homozygous at the candidate gene locus stating as the parental-generation. Afterwards, an intercross between the heterozygous $\mathrm{F}_{1}$-animals or, alternatively, a backcross to the parental breed is performed in order to produce the $\mathrm{F}_{2}$ - or backcross generation that includes all genotypes in expected Mendelian ratios. Then, the sows of the $\mathrm{F}_{2}$ or backcross generation can be genotyped and phenotyped. A disadvantage is, that similar to QTL analyses, this procedure is also time consuming. In principle, a direct candidate gene approach can be recommended when it is known that a gene product has a measurable influence on a phenotypical trait (physiological candidate gene) or that a gene is located in a narrowed QTL region (positional candidate gene) or that the candidate gene has an influence on the phenotypical trait in other species (comparative candidate gene). The more reasons for a candidate gene approach are given, the higher is the probability to detect a real effect for the chosen gene.

\section{Construction of a cytogenetic map harboring QTL and candidate genes for fecundity}

In 1997, Rothschild et al. reviewed for the first time approaches to improve fecundity in pigs on the molecular level. More recent reviews in this field were presented by Omelka et al. (2001) and by Rothschild (2004). Alfonso (2005) conducted a meta-analysis concerning the PvuII polymorphism for ESR genotypes for litter size in swine. It has been shown that combining the results across studies can provide a more precise and consensus estimate of the effect of a candidate gene as compared with any single study. The objective of our study was to combine results from QTL mapping and candidate gene approaches to provide a cytogenetic map with all up to date known QTL and candidate genes influencing reproductive traits in pigs. Until now, this has been performed for production and fecundity traits only for single chromosomes, such as for SSC1 (Smith et al., 2001) and for SSC10 (Nonneman and Rohrer, 2003). In order to present a complete cytogenetic map, each publication which reported a QTL or a candidate gene for such a trait was adducted. For the construction of the map, we used all available data on reproductive traits. Reproductive traits were teat number, gestation length, age of puberty, uterine capacity, ovulation rate and litter size parameters comprising the total number of born piglets, the number of born alive piglets and the number of stillborn piglets. The method for the construction of the cytogenetic map was the following: in cases where the cytogenetic position of the observed QTL was given, this region was directly adopted and drawn into the genome map. Most authors, however, gave the position of a QTL in centiMorgan (cM) in a linkage map. Because the presented linkage maps differed among studies, it was difficult to find consensus QTL regions. Therefore we converted the QTL-linked marker positions into a cytogenetic position. For this purpose, first, it was shown at which marker the highest F-ratio was found or, alternatively, between which markers the confidence interval representing the most likely position of the QTL was observed. The next step was to evaluate the cytogenetic position of these markers by using several databases (listed at the end of this article). When the cytogenetic position of those markers was not evaluable, the closest linked marker(s) to the reported marker(s) was used and its cytogenetic position was examined as described above. When a cM position was given only and the kind of genotyped markers (in most cases microsatellites) referred to other publications, these publications were consulted in order to determine the cytogenetic position as described above. In a few cases, it was impossible to determine any cytogenetic position of a QTL because of the absence of any cytogenetic position of markers. Then, the QTL was added without further localization to a chromosomal region in that way, that a line was drawn below the adequate chromosome. Furthermore, we distinguished 
between QTL above and below the genome-wide significance threshold of $\alpha=0.05$. The cytogenetic positions of the candidate genes were identified by the use of the same databases and included into our map.

\section{Results of linkage and association studies for subtraits of fecundity}

Table 2 shows the currently mapped QTL regions with influence on fecundity in pigs with a level of significance at $p<0.05$. Further information concerning chromosome number, crossbreeding system, number of genotyped $\mathrm{F}_{2}$-animals, recorded trait and the reference are also presented. In Table 3 we present all currently known candidate genes with potential influence on reproductive traits. Further information concerning the location on the chromosome as well as the polymorphism, the number of genotyped animals, the observed trait and the reference are also presented.

\subsection{Teat number}

Fig. 1 shows that most QTL were found for teat number, likely because this trait is easy to measure. Significant QTL for teat number were found on SSC1 and SSC7 (Wada et al., 2000), on SSC2 and SSC12 (Hirooka et al., 2001), on SSC8 (Cassady et al., 2001; King et al., 2003), on

Table 2

QTL for reproductive traits in pigs $(p<0.05)$

\begin{tabular}{|c|c|c|c|c|}
\hline $\mathrm{SSC}$ & Crossbreeding & $\begin{array}{l}\text { No. of } \\
\text { genotyped } \\
\mathrm{F}_{2} \text {-pigs }\end{array}$ & Trait & References \\
\hline $8,13,15$ & Large White $\times$ Landrace & 114 & Ovulation rate & Rathje et al. (1997) \\
\hline 4 & Yorkshire $\times$ Meishan & 122 & $\begin{array}{l}\text { Number of stillborn } \\
\text { piglets }\end{array}$ & Wilkie et al. (1999) \\
\hline 8 & & & Ovulation rate & \\
\hline 9 & & & Gestation length & \\
\hline 8 & White composite $\times$ Meishan & $295^{\mathrm{a}}$ & Ovulation rate & Rohrer et al. (1999) \\
\hline 6 & Göttingen miniature pig $\times$ Meishan & 143 & Litter size & Yasue et al. (1999) \\
\hline 10 & White composite $\times$ Meishan & 750 & Teat number & Rohrer (2000) \\
\hline 1,7 & Göttingen miniature pig $\times$ Meishan & 265 & Teat number & Wada et al. (2000) \\
\hline 7 & Large White/Landrace $\times$ Meishan & 249 & $\begin{array}{l}\text { Total number born; } \\
\text { litter } 1\end{array}$ & De Koning et al. (2001) \\
\hline $12,14,17$ & & & $\begin{array}{l}\text { Total number born; } \\
\text { litter } 2\end{array}$ & \\
\hline 8 & Yorkshire $\times$ Meishan & 108 & Ovulation rate & Braunschweig et al. (2001) \\
\hline 7,8 & Large White $\times$ Landrace & 423 & Age of puberty & Cassady et al. (2001) \\
\hline 9 & & & Ovulation rate & \\
\hline 8,11 & & & Teat number & \\
\hline 5,13 & & & $\begin{array}{l}\text { Number of stillborn } \\
\text { piglets }\end{array}$ & \\
\hline 11 & & & Fully formed piglets & \\
\hline $2,10,12$ & Large White/Landrace $\times$ Meishan & 1173 & Teat number & Hirooka et al. (2001) \\
\hline 8 & White composite $\times$ Meishan & $600^{\mathrm{a}}$ & Ovulation rate & Campbell et al. (2003) \\
\hline 8 & Large White $\times$ Meishan & 220 & Teat number & King et al. (2003) \\
\hline 8 & & & Number born alive & \\
\hline
\end{tabular}

${ }^{\mathrm{a}} \mathrm{BC}, \mathrm{F}_{3}, \mathrm{~F}_{4}$ generation together, followed by a backcross between the $\mathrm{F}_{1}$ and P-generation. 
Table 3

Candidate genes with association to reproductive traits in pigs

\begin{tabular}{|c|c|c|c|c|c|c|}
\hline Gene & SSC & Polymorphism & $\begin{array}{l}\text { Breed/ } \\
\text { crossbreeding }^{\text {a }}\end{array}$ & $\begin{array}{l}\text { No. of } \\
\text { genotyped } \\
\text { pigs }\end{array}$ & Trait $^{\mathrm{b}}$ & References \\
\hline \multirow[t]{8}{*}{ ESR } & \multirow[t]{8}{*}{1} & Intron $^{c}$ & $(\mathrm{M} \times \mathrm{SL}) ; \mathrm{LW}$ & 161 and $1079^{d}$ & TNB, NBA & $\begin{array}{l}\text { Rothschild et al. } \\
\text { (1996) }\end{array}$ \\
\hline & & No information & LW & 4262 & $\begin{array}{l}\text { TNB, NBA, Teat } \\
\text { number }\end{array}$ & Short et al. (1997) \\
\hline & & No information & $\mathrm{CB}$ & 262 & TNB, NBA & Chen et al. (2000) \\
\hline & & Intron & $(\mathrm{M} \times \mathrm{LW})$ & 275 & TNB, NBA & Van Rens et al. (2002) \\
\hline & & No information & LW & 74 and $124^{\mathrm{d}}$ & TNB, NBA & Matoušek et al. (2003) \\
\hline & & No information & LW & 1030 & TNB, NBA & $\begin{array}{l}\text { Goliášová and Wolf } \\
\text { (2004) }\end{array}$ \\
\hline & & No information & LW & 226 & TNB, NBA & Horogh et al. (2005) \\
\hline & & Exon 8 & Lr; SL & 144 & NBA & Depuydt et al. (1999) \\
\hline \multirow[t]{5}{*}{ PRLR } & \multirow[t]{5}{*}{16} & No information & LW & 400 & NBA & Vincent et al. (1998) \\
\hline & & No information & $\mathrm{M}, \mathrm{Lr}$ & 261 and 416 & TNB, NBA & Vincent et al. (1998) \\
\hline & & No information & SL & 273 & NBA & $\begin{array}{l}\text { Drogemuller et al. } \\
\text { (2001) }\end{array}$ \\
\hline & & No information & $(\mathrm{M} \times \mathrm{LW})$ & 77 & $\begin{array}{l}\text { Age of puberty, } \\
\text { TNB, NBA }\end{array}$ & $\begin{array}{l}\text { Van Rens and Van der } \\
\text { Lende (2002a) }\end{array}$ \\
\hline & & Exon $^{\mathrm{e}}$ & $(\mathrm{M} \times \mathrm{LR})$ & 55 & $\begin{array}{l}\text { Ovulation rate, } \\
\text { Uterine length }\end{array}$ & Van Rens et al. (2003) \\
\hline \multirow[t]{2}{*}{$\mathrm{FSHb}$} & \multirow[t]{2}{*}{2} & Intron & $(\mathrm{YS} \times \mathrm{EL})$ & 289 & TNB, NBA & Li et al. (1998) \\
\hline & & Promotor & LP; DP; Lr & No information & Litter size & Du et al. (2002) \\
\hline RBP4 & 14 & Intron & SL & 1300 & TNB, NBA & $\begin{array}{l}\text { Rothschild et al. } \\
(2000)\end{array}$ \\
\hline GNRHR & 8 & $3^{\prime} \mathrm{UTR}$ & $(\mathrm{M} \times \mathrm{LW})$ & 200 & Ovulation rate & Jiang et al. (2001) \\
\hline \multirow[t]{3}{*}{ LEP } & \multirow[t]{3}{*}{18} & Exon $3^{f}$ & SL & 519 & $\begin{array}{l}>1 \text { litter TNB, } \\
\text { NBA }\end{array}$ & $\begin{array}{l}\text { Korwin-Kossakowska } \\
\text { et al. (2002) }\end{array}$ \\
\hline & & Exon 3 & Ys; Lr & 62 and 170 & $\begin{array}{l}\text { Litter size, } 1-4 \\
\text { parity }\end{array}$ & Chen et al. (2004b) \\
\hline & & Intron 1 & $\mathrm{Du}$ & 246 & 1 litter & Chen et al. (2004b) \\
\hline LEPR & 6 & $\begin{array}{l}\text { Intron 2, Exon 2, } \\
\text { Exon } 18\end{array}$ & Ys, Du & 62 and 246 & $\begin{array}{l}\text { Litter size, } 1-4 \\
\text { parity }\end{array}$ & Chen et al. (2004a) \\
\hline $\mathrm{OPN}^{\mathrm{g}}$ & 8 & Intron & SL & 519 & $\begin{array}{l}>1 \text { litter, TNB, } \\
\text { NBA }\end{array}$ & $\begin{array}{l}\text { Korwin-Kossakowska } \\
\text { et al. }(2002)\end{array}$ \\
\hline $\mathrm{BF}$ & 7 & Intron 1 & $(\mathrm{LW} \times \mathrm{Lr}) \times \mathrm{Lc}$ & 123 & $\begin{array}{l}\text { TNB, NBA, 2-4 } \\
\text { parity }\end{array}$ & Buske et al. (2005) \\
\hline FUT1 & 6 & Exon 2 & PBP & 104 & $\begin{array}{l}\text { TNB, NBA, 1-6 } \\
\text { parity }\end{array}$ & Horák et al. (2005) \\
\hline EPOR & 2 & Intron 4 & $(\mathrm{Ys} \times \mathrm{Lr} \times \mathrm{CW} \times \mathrm{LW})$ & 402 & Uterine capacity & Vallet et al. (2005) \\
\hline
\end{tabular}

${ }^{a} \mathrm{CB}=$ Chinese breeds, $\mathrm{CW}=$ Chester White $\mathrm{DP}=$ Duli pigs, Du=Duroc, $\mathrm{EL}=$ Erhualian line, Lc=Leicoma, $\mathrm{LP}=$ Laiwu pigs, $\mathrm{Lr}=$ Landrace, $\mathrm{LW}=$ Large White, $\mathrm{M}=$ Meishan, $\mathrm{PBP}=$ Přeštice Black-Pied, SL=Synthetic line, Ys $=$ Yorkshire.

b $\mathrm{TNB}=$ total newborn, $\mathrm{NBA}=$ newborn alive.

c Personal communication by M. Rothschild in Van Rens et al. (2002).

d Two investigations.

e Personal communication by M. Rothschild in Van Rens et al. (2003).

f In Chen et al. (2004b).

g $\mathrm{OPN}=\mathrm{SPP} 1$. 

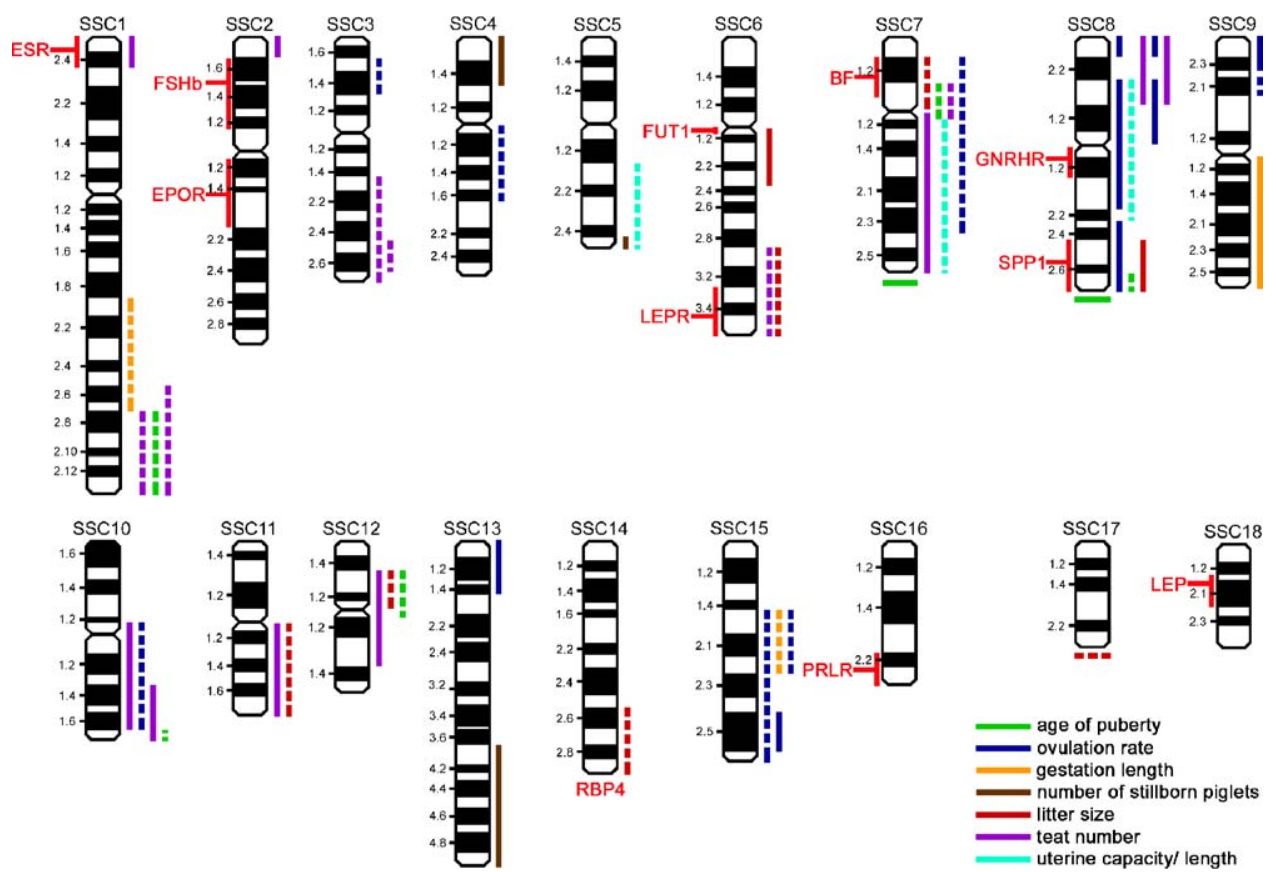

Fig. 1. Cytogenetic map of the pig with all QTL and candidate genes influencing fecundity. Figure legend: bold solid lines $=$ level of significance $p<0.05$; dashed lines $=$ level of significance $p>0.05$; cytogenetic positions of the lines at the end of the chromosomes and for RBP4 were not evaluable; $\mathrm{BF}=$ properdin; $\mathrm{ESR}=\mathrm{estrogen}$ receptor; $\mathrm{EPOR}=$ erythropoietin receptor; $\mathrm{FSHb}=$ follicle stimulating hormone beta; FUT1 = fucosyltransferase 1; GNRHR = gonadotropin releasing hormone receptor; $L E P=$ leptin; $L E P R=$ leptin receptor; $P R L R=$ prolactin receptor; $\mathrm{RBP} 4=$ retinol-binding protein 4; SPP1 $(\mathrm{OPN})=$ secreted phosphoproteine 1.

SSC10 (Rohrer, 2000; Hirooka et al., 2001), and on SSC11 (Cassady et al., 2001). It is interesting to note that on chromosomes 8 and 10, where two QTL were found independently, the QTL overlap very well. So it can be assumed, that one or more genes are located in this region influencing this trait. Furthermore, putative QTL were found on SSC1 (Rohrer, 2000; Cassady et al., 2001), SSC3 (Rohrer, 2000; Hirooka et al., 2001), SSC6 and SSC7 (Cassady et al., 2001). The analysis of the estrogen receptor gene has shown an influence on teat number (Short et al., 1997). The cytogenetic position of this gene is located within the QTL region on SSC1 with influence on this trait. Teat number plays a significant role when many piglets are born. Hence, the selection on litter size may require the increase of teat number (Hirooka et al., 2001). However, although teat number is easy to measure in both, males and females, it is not likely to include this trait into MAS programs because firstly, there is no major QTL effect and thus, the question arises for which chromosomal region should be selected for in commercial pig production. Secondly, there are other, more important traits affecting reproduction performance in pigs such as ovulation rate and uterine capacity (Bennett and Leymaster, 1989). Moreover, pleiotropic effects between increased teat number and reduced ovulation rate in Meishan pigs have been reported (Rohrer, 2000).

\subsection{Gestation length}

Wilkie et al. (1999) found one significant QTL for gestation length on the q-arm on SSC9 and two putative QTL on SSC1 and SSC15. The effect of the QTL on SSC9 contributed to a 
reduction of the gestation length by 3.04 days for the alleles from the Yorkshire founder sows in comparison to the Meishan founder boars. An imprinting effect, however, was not observed. As shown in Fig. 1, the two putative QTL on SSC1 and SSC15 for gestation length overlap well with the QTL for age of puberty on SSC1 (Rohrer et al., 1999) and ovulation rate on SSC15 (Wilkie et al., 1999), respectively. Because King et al. (2003) observed that sows with shorter gestation periods had higher levels of prenatal survival, this trait has potential to be introduced into MAS.

\subsection{Age of puberty}

Several QTL have been detected for age of puberty. Cassady et al. (2001) detected a suggestive QTL for this trait on the telomeric end of the q-arm on SSC8. A further suggestive QTL was detected on SSC7 by the same authors, but the cytogenetic position of this QTL was not evaluable. Additional putative QTL for this trait have been mapped on SSC1 and SSC10 (Rohrer et al., 1999), and on SSC7, SSC8 and SSC12 (Cassady et al., 2001). It must be noticed that none of the observed QTL overlap each other, thus, it can be expected that for this trait, many different genes are responsible. The prolactin receptor gene (PRLR) on SSC16 as a physiological candidate gene has shown association with age of puberty. Van Rens and Van der Lende (2002a) observed that gilts with the genotype BB were significantly younger at the age of first estrus compared to AA gilts. However, pleiotropic effects with other traits, such as litter size have been observed within the same animals. Therefore, it can be assumed that PRLR will rather not serve as a marker for MAS to reduce the age of puberty.

\subsection{Uterine capacity, uterine length}

Uterine capacity is a major component contributing to litter size in pigs (Christenson et al., 1987; Leymaster and Johnson, 1994). Because this trait is a limiting factor for high litter size, researchers focused on it despite the fact that this trait is difficult to measure. That is why less investigations have been performed for uterine parameters in relation to ovulation rate and litter size parameters. For uterine length, Wilkie et al. (1999) found a QTL on SSC5 and SSC7. Rohrer et al. (1999) observed a QTL for uterine capacity on SSC8, but, until now, none of these QTL have been confirmed. Van Rens et al. (2003) investigated the PRLR gene on SSC16 with regard to uterine length and found significant differences between genotypes. Recently, Vallet et al. (2005) found an association between the erythropoietin receptor gene (EPOR) and uterine capacity in two distinct sow populations. They investigated a single nucleotide polymorphism (SNP) in intron 4 of a total of 402 gilts and concluded that selection of the favorable genotype could increase litter size in swine that are not limited in ovulation rate. A further candidate gene for uterine capacity could be the estrogen sulfotransferase gene (STE). It is located on SSC8 and Kim et al. (2002) observed different mRNA expression levels in Meishan and White composite pigs during pregnancy. Furthermore, in cyclic gilts, uterine STE activity increases during the luteal phase of the cycle (Pack and Brooks, 1974).

\subsection{Ovulation rate}

Ovulation rate is surely one of the most important traits for reproduction because it directly influences litter size. Therefore, many studies focused on this trait. Until now, a total of 15 QTL affecting ovulation rate has been observed, most of them on SSC8. The first significant QTL analysis affecting reproductive traits in pigs was performed by Rathje et al. (1997). They found 
a QTL for ovulation rate at the telomeric end of the long arm on SSC8. For this trait, Wilkie et al. (1999) found a QTL near the centromere and Rohrer et al. (1999) found a QTL at the telomeric end of the short arm of the same chromosome. Thus it can be concluded, that SSC8 likely harbors several genes influencing ovulation rate. Recent studies confirmed and narrowed these regions for the mapped QTL on SSC8. Braunschweig et al. (2001) refined the genetic map by the use of 29 markers and confirmed the QTL at the centromere region of SSC8. Campbell et al. (2003) narrowed the region at the telomeric end of the short arm on SSC8 using gene and microsatellite markers within the first $27 \mathrm{cM}$ and confirmed and narrowed the QTL found by Rohrer et al. (1999). Additional significant QTL for ovulation rate were found on SSC9 (Cassady et al., 2001), SSC13 and SSC15 (Rathje et al., 1997). Putative QTL were found on SSC3, SSC9, SSC10, and SSC15 (Rohrer et al., 1999), on SSC4 (Rathje et al., 1997), and on SSC7 and SSC15 (Wilkie et al., 1999). The QTL identified by Rohrer et al. (1999) on SSC15 did overlap both with the QTL identified by Wilkie et al. (1999) and by Rathje et al. (1997).

Concerning candidate gene approaches, Jiang et al. (2001) investigated the gonadotropinreleasing hormone receptor gene (GNRHR) for ovulation rate because of the observation of QTL for ovulation rate on SSC8 and because of the fact that GNRHR is critical in the endocrine regulation of reproduction. This gene is located at 8q11-q12 near the centromere where Wilkie et al. (1999) and Braunschweig et al. (2001) found a QTL for ovulation rate. A significant association between the $\mathrm{C} / \mathrm{G}$ substitution in the $3^{\prime} \mathrm{UTR}$ and the number of corpora lutea at first parity was observed, so it can be assumed that GNRHR could have an effect on ovulation rate in pigs. Van Rens et al. (2003) investigated the prolactin receptor gene (PRLR) on SSC16 for different reproductive traits and found a significantly higher ovulation rate for AA genotypes in comparison to BB genotypes. However, until now, no QTL for this trait has been detected there.

\subsection{Number of stillborn piglets}

Significant QTL for the number of stillborn piglets were found on SSC4 (Wilkie et al., 1999), on SSC5 and SSC13 (Cassady et al., 2001). Until now, no candidate gene has been tested for this region. However, Sun et al. (2002) investigated the POU domain class 1 transcription factor 1 (POU1F1) gene on SSC13 with regard to growth hormone and prolactin concentrations in blood serum of growing sows and found differences among genotypes. As these hormones are critical for the development of mammals, POU1F1 could be a candidate gene concerning the number of stillborn piglets.

\subsection{Litter size}

Measuring litter size as a reproductive trait is easy and the most important trait for pig producers. However, it must be taken into consideration that there is no single gene responsible for litter size itself. This trait is influenced by several traits such as uterine capacity, ovulation rate and embryonic viability (Bennett and Leymaster, 1989). Bennett and Leymaster (1989) concluded that selection for these multiple traits is required in order to attain progress in litter size. Significant QTL regions for litter size are located on SSC8 (King et al., 2003) and on SSC11 (Cassady et al., 2001). Putative QTL regions are located on SSC6 (Wilkie et al., 1999), SSC7, SSC12, SSC14 and SSC17 (De Koning et al., 2001). 
The leptin receptor gene (LEPR) could be the gene underlying the QTL effect on SSC6, which has been identified by Wilkie et al. (1999). Chen et al. (2004a) found differences between genotype groups for polymorphisms in intron 2, exon 2 and exon 18 of the LEPR gene for litter size in Duroc and Yorkshire sows. Another region with influence on litter size is located on the q-arm on SSC6, however, no level of significance has been reported (Yasue et al., 1999). In this region, 20 genes, which are homologue to human chromosome 19, were registered including the pregnancyspecific beta-1-glycoprotein (PSG1) as the most probable candidate gene. Korwin-Kossakowska et al. (2002) investigated the osteopontin gene $(\mathrm{OPN}=\mathrm{SPP} 1)$ for litter size on SSC8 due to the known homology between this region in pigs and the ovine chromosome 6 , where the high prolificacy gene $(\mathrm{FecB})$ is located. OPN maps to $8 \mathrm{q} 2.5-2.7$ and is located in the region, where QTL for litter size (King et al., 2003) and ovulation rate (Rathje et al., 1997) have been found. For later parities, significantly more piglets (TNB and NBA) were observed for the osteopontin genotype AA in comparison to the heterozygous and homozygous BB genotypes.

Many investigations have shown that the estrogen receptor gene (ESR), which is located on SSC1 has an influence on litter size in pigs (Table 3), but, contrary to these findings, there are also many studies which cannot confirm these results (Rohrer et al., 1999; Drogemuller et al., 2001; Lineville et al., 2001; Gibson et al., 2002; Isler et al., 2002; Horák et al., 2005). General debate exist now, whether the analyzed ESR polymorphism has a direct impact on litter size or not. For example, Rothschild et al. (1996) and Short et al. (1997) observed, that the BB genotype is favorable concerning litter size parameters such as TNB and NBA, whereas Goliášová and Wolf (2004) reported, that the AA genotype is favorable with regard to the same litter size parameters. They concluded that ESR allelic effects can differ between populations. Obviously the investigated ESR alleles are linked with different alleles of the causative mutation in different populations. In addition to direct effects, allelic effects may differ between different populations as a result of epistatic interaction with the population specific genetical background. Further reasons for the different findings concerning the ESR gene effects might be for example, that the number of analyzed animals and populations varied between studies considerably. Furthermore, one can assume that environmental influences and genetical background were not the same between studies and such effects could overlay small direct effects of the estrogen receptor gene. Moreover, the investigated polymorphism differed among studies (PvuII and AvaI restriction sites). Whereas most authors investigated the PvuII restriction site in an intron region according to Short et al. (1997), Depuydt et al. (1999) investigated both restriction sites for litter size. Interestingly, an association between litter size and ESR genotypes was only observed for the AvaI restriction site, but not for the former one. Because of the fact that association studies between the ESR PvuII mutation and litter size in pigs differed to a considerable amount, recently, Alfonso (2005) performed a meta-analysis, comprising 15 published studies including 9329 sows. He could show, that finally, the B allele is superior for TNB and for NBA piglets. However, no QTL has been found in the chromosomal region where the ESR gene is located for any reproductive trait, except teat number. From these studies one can conclude that the genetic effect of a possible ESR variant is rather small. This also explains, that in pedigree analyses with small sample sizes no additional QTL on SSC1 has been detected. Furthermore, the ESR gene might not have been polymorphic in the populations involved in the QTL scans. Van Rens et al. (2002) stated that the ESR gene is rather a marker than the causative gene itself. Pleiotropic effects for the ESR gene have also been reported. Van Rens and Van der Lende (2002b) observed, that the favorable allele for litter size appears to be the unfavorable allele for pre-weaning piglet growth.

Muñoz et al. (2004) investigated a polymorphism in exon 5 of the ESR2 gene which is located at the telomere of the q-arm of SCC1 in two Iberian pig populations with 46 and 150 sows, 
respectively. In this study no statistically significant association between the ESR2 polymorphism and litter size was found. The authors recommended to repeat this association study by expanding sample size.

Other candidate genes with a potential influence on litter size are the follicle stimulating hormone gene beta (FSHb) on SSC2 (Li et al., 1998), the leptin gene (LEP) on SSC18 (KorwinKossakowska et al., 2002; Chen et al., 2004b) and the retinol-binding protein 4 (RBP4) on SSC14 (Rothschild et al., 2000). Whereas no QTL effects have been detected for the genomic position of FSHb and LEP, a putative QTL for litter size has been detected on SSC14. As the cytogenetic position of RBP4 is not clearly defined, it is not sure whether the effects of the RBP4 gene might be responsible for the reported SSC14 QTL.

\subsection{Genomic distribution of identified genetic effects}

Fig. 1 shows that all autosomes harbor QTL or candidate genes with impact on fecundity. However, on chromosome 8, and, to a lower extend on chromosome 7 comparatively many QTL for reproductive traits have been identified.

At the telomeric end of the p-arm and the centromeric region of SSC8, the QTL for ovulation rate could be confirmed and narrowed, respectively. At the centromeric region, also a QTL for uterine capacity has been reported. If ovulation rate and uterine capacity have an effect on litter size, we would expect in this chromosomal region also a QTL or at least one gene influencing litter size. However, until now, no genetic effect on litter size has been found in this region. At the telomeric end of the q-arm of SSC8, a QTL for ovulation rate and one for litter size have been reported. As these parameters are in a physiological context, one can speculate that one gene might be responsible for these two traits. A positional candidate gene could be SPP1, which obviously has an influence on litter size (Korwin-Kossakowska et al., 2002).

Similar conclusions can be drawn for SSC7, especially for the centromeric region, where QTL for ovulation rate, number of stillborn piglets and for litter size are located. As these traits are also in a physiological context, one or more genes contributing to the phenotypic variance can be expected. It is interesting to note that exactly at this region the major histocompatibility complex (MHC) is located (Peelman et al., 1996; Ponsuksili et al., 2001). The MHC is a relatively dense gene cluster, which could harbor one or more genes influencing reproductive traits in swine (Vaiman et al., 1998). Within the MHC, the properdin gene (BF) is located, and Buske et al. (2005) found an association between BF genotypes and litter size in a commercial pig cross-population. Furthermore, Gautschi and Gaillard (1990) observed influences on litter size of this chromosomal region in targeted mating studies.

Another interesting chromosome is SSC5 because of the overlapping QTL for stillborn piglets and uterine length. If there are many conceptuses, but the uterine length is not long enough at the same time, the conceptuses cannot develop and thus the number of stillborn piglets increases. SSC6 is particularly interesting because of the economically important QTL for litter size. Recently, Horák et al. (2005) reported an association between the fucosyltransferase 1 gene (FUT1) on SSC6 and litter size in Přšstice Black-Pied sows.

\section{Discussion}

Leymaster and Johnson (1994) concluded that selection for high ovulation rate and uterine capacity might produce the greatest response to increase litter size. However, these parameters are difficult to measure simultaneously in the same animals, because both traits are measurable 
simultaneously only for one parity once in an animal. Until now, Rohrer et al. (1999), Wilkie et al. (1999) and Isler et al. (2002) are the only ones who investigated both traits in the same animals. If ovulation rate and uterine capacity have an effect on litter size, QTL for litter size is expected in the same genomic region as for either QTL for ovulation rate or for uterine parameters, respectively. As several significant QTL were initially found on SSC8, in recent years fine mapping has been started for this chromosome. Consequently, at this time there is a clear bias in favor of investigations on SSC8. In future, fine mapping should be extended on other chromosomes, e.g. on SSC7, where also several QTL effects were found.

During the last years, a large number of reports on QTL and candidate genes with influence on reproductive traits of sows have been published. Inspection of these reports indicates interesting overlapping results among some studies, but also remarkable differences in the location of QTL and in the estimated size and magnitude of the effects of individual QTL and candidate genes. The reasons for this phenomenon are essentially due to differences in the experimental setup. There are differences between resource populations such as different breeds, number of evaluated animals and mating systems, leading to different genotype- and allele frequencies. Differences in genetical background and environmental influences may enhance or inhibit gene effects. Several models for the statistical analyses and the determination of the significance thresholds have been applied. Another aspect is that candidate genes or QTL were investigated with regard to slightly differing traits belonging all to the term "reproduction". As a result, the estimated effect size and the conclusions of the studies varied to a considerable extent. Consequently, there is a need to determine consensus locations of QTL and genes as well as estimates of the effects for the phenotypical traits. The probability that identified effects on fecundity parameters in sows are real effects and typical for a larger population is higher for chromosomal regions, for which QTL or gene effects have been confirmed in different populations. Chromosomal regions, which have been found in one population only may be caused by population specific seldom allelic variant or might result from multiple statistical tests just by chance. QTL, which have been identified with high genome wide significance threshold of $p<0.01$ are more likely real effects than suggestive QTL at the chromosome-wide significance threshold of $p<0.05$. The latter needs confirmation in different populations to show that these are real effects.

As shown in Fig. 1, so far no QTL effects were identified in chromosomal regions, where potential influences of candidate genes like PRLR, LEP, and FSHb for reproductive traits were found. This could be explained by smaller sample sizes for QTL scans in comparison to candidate gene approaches and the possibility that candidate genes did not have different alleles in segregating pedigrees.

In order to describe and interpret QTL analyses more precisely, Khatkar et al. (2004) gave useful suggestions in their meta-analysis. We extend these suggestions also for candidate gene approaches, particularly with regard to reproductive traits in pigs. Authors should follow the proposed guidelines. (1) For candidate genes, reasons for the selection should be explained, the chromosomal position, the gene identification number and the location of the polymorphism should be reported as well as the equation for the analysis of variance including all fixed effects and covariates. (2) An exact description of the population such as the number of genotyped animals, resource population (race, pedigree, genetical background, inbreeding level), mating regime (insemination regime, artificial or no) and environmental conditions (feeding and housing regimes) should be presented. (3) A detailed description of the measured phenotypical traits, the reason(s) for choosing the traits and in cases of traits such as litter size the number of replications (e.g., number of litters should be equal for each sow) is desirable. (4) For QTL studies, analytical method, marker map used, number of markers and their distances, QTL map positions and 
confidence intervals as well as closest markers are to declare. (5) Information concerning the test statistic (level of significance of reported $p$-values and their description: point-wise, chromosome-, or genome-wide) are necessary. (6) The estimated effect size should be given with standard errors, and if examined, known pleiotropic effects should be reported in detail for both, QTL analyses and candidate gene approaches. A precise recommendation for animal numbers for example is not possible, due to nescience of the size of genetic effects, or due to expected genotype frequencies (for candidate gene approaches). However, two important relations should be provided: regarding QTL analyses and particularly fine-mapping, an extension of marker density for example leads only to more precise results, when at the same time animal numbers are increased (Broman, 2001). Otherwise, additional information about QTL position is poor. Concerning candidate gene approaches, balanced genotype frequencies can lead to reduced animal numbers. Some candidate gene approaches lacked in that way, that one genotype was absolutely not, or only present in low numbers in a population, and therefore, a final conclusion on genotype effects is not feasible. It cannot be excluded, that the absent genotype could lead to phenotypical changes.

Although difficult to perform, a further advance would be a standardization of the experimental setup and methodologies to allow more transparent comparison and collation of results, as it is done for multi-centre clinical trials in human studies for example. Concerning candidate gene approaches, a targeted mating test would be an improvement in order to obtain balanced genotype frequencies. When such an experimental design is not available or feasible, at least the parents of the sows should be genotyped in order to identify, from which parent a desirable allele was inherited. Afterwards, genotype frequencies for a chosen gene should be investigated in a commercial population in order to preselect suitable parents for further genetic analyses in this population.

\section{Conclusions}

Fecundity in multiparous animals, especially in pigs, is one of the most difficult and complex traits. The reasons are in addition to low heritabilities, long generation intervals, the polygenic nature of reproductive traits and the strong environmental influences on reproduction processes. The inspection of all evaluated articles indicates similarities among some studies, but also remarkable differences concerning the location of QTL and the estimated size and magnitude of the effects of individual QTL and candidate genes. For further research, the present knowledge on QTL and candidate gene positions and effects should be used efficiently. Fine-mapping of QTL regions should be extended in order to narrow QTL intervals to reduce the number of positional candidate genes with regard to reproductive traits. A combination of fine mapping and candidate gene approaches for promising chromosomal regions is a straight forward strategy. We propose to present the information on identified QTL and candidate genes as accurately as possible and to standardize the methods in order to be able to compare the results among studies more precisely. Furthermore, emphasis should be given on traits which are economically important and preferably easy to measure, and pleiotropic effects for the chosen genes or QTL should be investigated as accurately as possible. Considering all these facts, selection progress is mainly achieved, when firstly a beneficial polymorphism is detected for a desirable trait and rare genotypes have been found in a commercial breed in order to increase this genotype in the population.

\section{Acknowledgement}

We thank the H. Wilhelm Schaumann Stiftung (Hamburg, Germany) for a grant for B. Buske. 


\section{Databases}

http://www.genome.iastate.edu/pig.

http://www.marc.usda.gov/genome/genome.html.

http://www.ncbi.nlm.nih.gov/.

http://www.projects.roslin.ac.uk/pigmap/pigmap.html.

http://ws4.niai.affrc.go.jp/dbsearch2/pmap/.

\section{References}

Alfonso, L., 2005. Use of meta-analysis to combine candidate gene association studies: application to study the relationship between the ESR PvuII polymorphism and sow litter size. Genet. Sel. Evol. 37, 417-435.

Bennett, G.L., Leymaster, K.A., 1989. Integration of ovulation rate, potential embryonic viability and uterine capacity into a model of litter size in pigs. J. Anim. Sci. 67, 1230-1241.

Braunschweig, M.H., Paszek, A.A., Weller, J.I., Da, Y., Hawken, R.J., Wheeler, M.B., Schook, L.B., Alexander, L.J., 2001. Generation and exploration of a dense genetic map in a region of a QTL affecting corpora lutea in a Meishan $\times$ Yorkshire cross. Mamm. Genome 12, 719-723.

Broman, K.W., 2001. Review of statistical methods for QTL mapping in experimental crosses. Lab. Anim. 30, 44-52.

Buske, B., Brunsch, C., Zeller, K., Reinecke, P., Brockmann, G., 2005. Analysis of properdin (BF) genotypes associated with litter size in a commercial pig cross population. J. Anim. Breed. Genet. 122, 259-263.

Campbell, E.M.G., Nonneman, D., Rohrer, G.A., 2003. Fine mapping a quantitative trait locus affecting ovulation rate in pigs on chromosome 8. J. Anim. Sci. 81, 1706-1714.

Cassady, J.P., Johnson, R.K., Pomp, D., Rohrer, G.A., Van Vleck, L.D., Spiegel, E.K., Gilson, K.M., 2001. Identification of quantitative trait loci affecting reproduction in pigs. J. Anim. Sci. 79, 623-633.

Chen, C.C., Chang, T., Su, H.Y., 2004a. Characterization of porcine leptin receptor polymorphisms and their association with reproduction and production traits. Anim. Biotechnol. 15, 89-102.

Chen, C.C., Chang, T., Su, H.Y., 2004b. Genetic polymorphisms in porcine leptin gene and their association with reproduction and production traits. Aust. J. Agric. Res. 54, 699-704.

Chen, K.F., Huang, L.S., Li, N., Zhang, Q., Luo, M., Wu, C.X., 2000. The genetic effect of estrogen receptor (ESR) on litter size traits in pig (in Chinese, with English abstract). Yi Chuan Xue Bao 27, 853-857.

Christenson, R.K., Leymaster, K.A., Young, L.D., 1987. Justification of unilateral hysterectomy-ovariectomy as a model to evaluate uterine capacity in pigs. J. Anim. Sci. 65, 738-744.

De Koning, D.J., Rattink, A.P., Harlizius, B., Groenen, M.A.M., Brascamp, E.W., Van Arendonk, J.A.M., 2001. Detection and characterization of quantitative trait loci for growth and reproduction traits in pigs. Livest. Prod. Sci. 72, $185-198$.

Depuydt, J., de Smet, S.T., Grijspeerdt, K., Herman, L., 1999. Association study of an AvaI and PvuII polymorphism at the porcine estrogen receptor (ESR) gene, with litter size. Archiv für Tierzucht 42, 172-174.

Drogemuller, C., Hamann, H., Distl, O., 2001. Candidate gene markers for litter size in different German pig lines. J. Anim. Sci. 79, 2545-2570.

Du, L.X., Liu, S.F., Yan, Y.C., Jiang, Y.L., 2002. Research on Alu element inserted mutation in porcine FSH beta subunit gene (in Chinese, with English abstract). Yi Chuan Xue Bao 29, 977-982.

Gautschi, C., Gaillard, C., 1990. Influence of major histocompatibility complex on reproduction and production traits in pigs. Anim. Genet. 21, 161-170.

Gibson, J.P., Jiang, Z.H., Robinson, J.A.B., Archibald, A.L., Haley, C.S., 2002. No detectable association of the ESR PvuII mutation with sow productivity in a Meishan $\times$ Large White $F_{2}$ population. Anim. Genet. 33, 448450.

Goliášová, E., Wolf, J., 2004. Impact of the ESR gene on litter size and production traits in Czech Large White pigs. Anim. Genet. 35, 293-297.

Hirooka, H., De Koning, D.J., Harlizius, B., Van Arendonk, J.A.M., Rattink, A.P., Groenen, M.A.M., Brascamp, E.W., Bovenhuis, H., 2001. A whole-genome scan for quantitative trait loci affecting teat number in pigs. J. Anim. Sci. 79, 2320-2326.

Holl, J.W., Robison, O.W., 2003. Results from nine generations of selection for increased litter size in pigs. J. Anim. Sci. $81,624-629$.

Horák, P., Urban, T., Dvořák, J., 2005. The FUT1 and ESR genes - their variability and associations with reproduction in Přšstice Black-Pied sows. J. Anim. Breed. Genet. 122, 210-213. 
Horogh, G., Zsolnai, A., Komlósi, I., Nyíri, A., Anton, I., Fésüs, L., 2005. Oestrogen receptor genotypes and litter size in Hungarian Large White pigs. J. Anim. Breed. Genet. 122, 56-61.

Isler, B.J., Irvin, K.M., Neal, S.M., Moeller, S.J., Davis, M.E., 2002. Examination of the relationship between the estrogen receptor gene and reproductive traits in pigs. J. Anim. Sci. 80, 2334-2339.

Jiang, Z., Gibson, J.P., Archibald, A.L., Haley, C.S., 2001. The porcine gonadotropin-releasing hormone receptor gene (GNRHR): genomic organization, polymorphisms, and association with the number of corpora lutea. Genome 44, 7-12.

Khatkar, M.S., Thomson, P.C., Tammen, I., Raadsma, H.W., 2004. Quantitative trait loci mapping in dairy cattle: review and meta-analysis. Genet. Sel. Evol. 36, 163-190.

Kim, J.G., Vallet, J.L., Rohrer, G.A., Christenson, R.K., 2002. Characterization of porcine uterineestrogen sulfotransferase. Domest. Anim. Endocrinol. 23, 493-506.

King, A.H., Jiang, Z., Gibson, J.P., Haley, C.S., Archibald, A.L., 2003. Mapping quantitative trait loci affecting female reproductive traits on porcine chromosome 8. Biol. Reprod. 68, 2172-2179.

Korwin-Kossakowska, A., Kamyczek, M., Cieślak, D., Pierzchala, M., Kuryl, J., 2002. The effect of the polymorphism of leptin (LEP), leptin receptor (LEPR) and osteopontin (OPN) genes on selected reproduction traits of synthetic Line 990 sows. Anim. Sci. Papers Rep. 20, 159-168.

Leymaster, K.A., Johnson, R.K., 1994. Second thoughts on selection for components of reproduction in pigs. In: Proceedings of the Fifth World Congress Genet. Livest. Prod., vol. 17, Guelph (Ont.), Canada, 7-12 August, p. 307.

Li, N., Zhao, Y.F., Xiao, L., Zhang, F.J., Chen, Y.Z., 1998. Candidate gene approach for identification of genetic loci controlling litter size in pigs. In: Proceedings of the Sixth World Congress Genet. Livest. Prod., vol. 26, Armidale, Australia, 11-16 January, pp. 183-190.

Lineville, R.C., Pomp, D., Johnson, R.K., Rothschild, M.F., 2001. Candidate gene analysis for loci affecting litter size and ovulation rate in pigs. J. Anim. Sci. 79, 60-67.

Matoušek, V., Kernerová, N., Kolaříková, O., Křrižová, I.I., Urban, T., Vrtková, I., 2003. Effect of RYR1 and ESR genotypes on the fecundity of sows of Large White breed in elite herds. Czech. J. Anim. Sci. 48, 129-133.

Muñoz, G., Óvilo, C., Amills, M., Rodríguez, C., 2004. Mapping of the porcine oestrogen receptor 2 gene and association study with litter size in Iberian pigs. Anim. Genet. 35, 242-244.

Nonneman, D.J., Rohrer, G.A., 2003. Comparative mapping of a region on chromosome 10 containing QTL for reproduction in pigs. Anim. Genet. 34, 42-46.

Omelka, R., Bauerova, M., Bulla, J., 2001. Genetic markers for reproductive traits in pigs. J. Agric. Sci. 47, 731740 .

Pack, B.A., Brooks, S.C., 1974. Cyclic activity of estrogen sulfotransferase in the gilt uterus. Endocrinology 95 , 1680-1690.

Peelman, L.J., Chardon, P., Vaiman, M., Mattheeuws, M., Van Zeveren, A., Van de Weghe, A., Bouquet, Y., Campbell, R.D., 1996. A detailed cytogenetic map of the porcine major histocompatibility complex (MHC) class III region: comparison with human and mouse MHC class III regions. Mamm. Genome 7, 363-367.

Ponsuksili, S., Wimmers, K., Yerle, M., Schellander, K., 2001. Mapping of 93 porcine ESTs preferentially expressed in liver. Mamm. Genome 12, 869-872.

Rathje, T.A., Rohrer, G.A., Johnson, R.K., 1997. Evidence for quantitative trait loci affecting ovulation rate in pigs. J. Anim. Sci. 75, 1486-1494.

Roehe, R., Kennedy, B.W., 1995. Estimation of genetic parameters for litter size in Canadian Yorkshire and Landrace pigs with each parity of farrowing treated as a different trait. J. Anim. Sci. 73, 2959-2970.

Rohrer, G.A., 2000. Identification of quantitative loci affecting birth characters and accumulation of backfat and weight in a Meishan-White composite resource population. J. Anim. Sci. 78, 2543-2547.

Rohrer, G.A., Ford, J.J., Wise, T.H., Vallet, J.L., Christenson, R.K., 1999. Identification of quantitative trait loci affecting female reproductive traits in a multigeneration meishan-white composite pigs population. J. Anim. Sci. 77, 1385-1391.

Rothschild, M.F., 2004. Porcine genomics delivers new tools and results: this little piggy did more than just to go to market. Genet. Res. 83, 1-6.

Rothschild, M.F., Jacobson, C., Vaske, D., Tuggle, C., Wang, L., Short, T., Eckardt, G., Sasaki, S., Vincent, A., McLaren, D., Southwood, O., Van der Steen, H., Mileham, A., Plastow, G., 1996. The estrogen receptor locus is associated with a major gene influencing litter size in pigs. Genetics 93, 201-205.

Rothschild, M.F., Messer, L.A., Vincent, A., 1997. Molecular approaches to improved pig fecundity. J. Reprod. Fertil. Suppl. 52, 227-236.

Rothschild, M.F., Messer, L., Day, A., Wales, R., Short, T., Southwood, O., Plastow, G., 2000. Investigation of the retinol-binding protein 4 (RBP4) gene as a candidate gene for increased litter size in pigs. Mamm. Genome 11, 75-77. 
Short, T.H., Rothschild, M.F., Southwood, O.I., McLaren, D.G., de Vries, A., Van der Steen, H., Eckardt, G.R., Tuggle, C.K., Helm, J., Vaske, D.A., Mileham, A.J., Plastow, G.S., 1997. Effect of the estrogen receptor locus on reproduction and production traits in four commercial pig lines. J. Anim. Sci. 75, 3138-3142.

Smith, T.P.L., Showalter, A.D., Sloop, K.W., Rohrer, G.A., Fahrenkrug, S.C., Meier, B.C., Rhodes, S.J., 2001. Identification of porcine Lhx3 and SF1 as candidate genes for QTL affecting growth and reproduction traits in pigs. Anim. Genet. $32,344-350$.

Sun, H.S., Anderson, L.L., Yu, T.P., Kim, K.S., Klindt, J., Tuggle, C.K., 2002. Neonatal Meishan pigs show POU1F1 genotype effects on plasma GH and PRL concentration. Anim. Reprod. Sci. 69, 223-237.

Vaiman, M., Chardon, P., Rothschild, M.F., 1998. Porcine major histocompatibility complex. Rev. Sci. Tech. Off. Int. Epizoot 17, 95-107.

Vallet, J.L., Freking, B.A., Leymaster, K.A., Christenson, R.K., 2005. Allelic variation in the erythropoietin receptor gene is associated with uterine capacity and litter size in swine. Anim. Genet. 36, 97-103.

Van Rens, B.T.T.M., Van der Lende, T., 2002a. Litter size and piglet traits of gilts with different prolactin receptor genotypes. Theriogenology 57, 883-893.

Van Rens, B.T.T.M., Van der Lende, T., 2002b. Piglet and placental traits at term in relation to the estrogen receptor genotype in gilts. Theriogenology 57, 1651-1667.

Van Rens, B.T.T.M., Hazeleger, W., Van der Lende, T., 2000. Periovulatory hormone profiles and components of litter size in gilts with different estrogen receptor (ESR) genotypes. Theriogenology 53, 1375-1387.

Van Rens, B.T.T.M., de Groot, P.N., Van der Lende, T., 2002. The effect of estrogen receptor genotype on litter size and placental traits at term in $\mathrm{F}_{2}$ crossbred gilts. Theriogenology 57, 1635-1649.

Van Rens, B.T.T.M., Evans, G.J., Van der Lende, T., 2003. Components of litter size in gilts with different prolactin receptor genotypes. Theriogenology 59, 915-926.

Vincent, A.L., Evans, G., Short, T.H., Southwood, O.I., Plastow, G.S., Tuggle, C.K., Rothschild, M.F., 1998. The prolactin receptor gene is associated with increased litter size in pigs. In: Proceedings of the Sixth World Congress Genet. Livest. Prod., vol. 27, Armidale, Australia, 11-16 January, pp. 15-18.

Wada, Y., Akita, T., Awata, T., Furukawa, T., Sugai, N., Inage, Y., Ishii, K., Ito, Y., Kobayashi, E., Kusumoto, H., Matsumoto, T., Mikawa, S., Miyake, M., Murase, A., Shimanuki, S., Sugiyama, T., Uchida, Y., Yanai, S., Yasue, H., 2000. Quantitative trait loci (QTL) analysis in a Meishan $\times$ Göttingen cross population. Anim. Genet. 31, 376-384.

Wilkie, P.J., Paszek, A.A., Beattie, C.W., Alexander, L.J., Wheeler, M.B., Schook, L.B., 1999. A genomic scan of porcine reproductive traits reveals possible quantitative trait loci (QTLs) for number of corpora lutea. Mamm. Genome 10, 573-578.

Yasue, H., Mikawa, S., Uenishi, H., Wada, Y., 1999. Analysis of allele segregation distortion in a pigs resource family. Anim. Biotechnol. 10, 147-152. 